President Arthur Gibson: The next paper by Messrs. Crawford and Spencer is one of a series.

\title{
THE EUROPEAN CORN BORER (Pyrausta nubilalis Hubn.): LIFE HISTORY IN ONTARIO ${ }^{1}$
}

\section{By H. G. Crawford, Eniomological Branch, Ottawa, and G. J. SPENCER, Ontario Agricultural College, Guelph, Ont.}

The apology for presenting so incomplete a study rests upon the fact that this is a recently introduced and already widely distributed insect, spreading with great rapidity, and capable of doing very serious damage. Consequently its reaction to Canadian conditions where it has demonstrated its ability to increase over 300 per cent in a single year and where its presence results in severe damage to our corn crop, cannot but be of interest and value.

The larvae of the European corn borer normally winter in corn stalks or stubble, either standing or lying on the ground. Almost any other not absolutely submerged shelter, from corn leaf on the ground to the centre of the cob in the crib, will serve for successful wintering. In the spring as soon as the weather warms up, the larvae do a variable amount of boring and possibly feeding in preparing the pupal chambers from which an outlet for the escape of the adult is made.

Pupation in the field in 1921 began on May 30th, being practically complete by June $22 \mathrm{~d}$, though one or two larvae were taken in the following week. Adults began to emerge June 16th and by July 4th 90 per cent of the moths had issued, the balance following more slowly; a small percentage failed to develop.

In the laboratory where the whole process of development was delayed, pupation did not begin until June 6th, ten days later. The males began to pupate 7 days before the females, outnumbering them until just before the end of the pupation period. Similarly with the moths, the males began to emerge about 4 days before the females and exceeded them in number until just before the end of the emergence period, which extended from June 29th to August 12th. The duration of the pupation period of the males varied from 8 to 18 days, an average of 12.33 days, while for the females it was distinctly less, from 7 to 17 days, an average of 11.29. At the laboratory located a little further inland the average durations, however, were 12 days for males and 10.19 for females, a distinctly more rapid rate.

${ }^{1} \mathrm{~A}$ joint progress report of the life history studies carried on at the laboratories of the Dominion and Ontario Departments of Agriculture in the season of 1921, at Port Stanley, Ontario, Canada. 
The male moths lived in confinement for from 6 to 21 days, averaging 13 days, while the females lived for from 10 to 31 days, averaging 17.4 days, with a pre-oviposition period (20 females) of from 3 to 9 days, averaging 4 days. After this pre-oviposition period they laid from 95 to 988 eggs per female, at the rate of from 12-231, an average of 75.3 eggs per day, in masses containing from 1-64 eggs, an average of 33 per mass. All of the eggs kept under observation hatched. The duration of this stage was from 3 to 8 days, averaging for the period between June 28th and August 2d 4.71 days.

In the field a study of the incidence of egg laying on corn planted on May 31st in a field adjacent to the northern margin of an old corn patch of 1920 at this time in oats and barley, was started. The moths began to emerge on June 18th from the old stubble in the standing grain, and eggs were not found until July 1st when 5 masses were secured from 100 plants though a most careful search was maintained in the intervening period of 14 days; on July $3 \mathrm{~d} 15$ masses were secured on approximately 200 plants, at which time egg laying was becoming general and some masses were observed to be hatching. The corn at this time was from 9-20 inches high. No eggs were laid until the corn averaged about 15 inches in height. In the interval the adults were, without doubt, flying southwest to another field planted on May 18th, which at this time was markedly in advance of the field under observation in development and finally suffered a loss of $65 \%$. The field under study on the north, howvever, was but $63.2 \%$ infested and the loss would not exceed $5 \%$.

The first eggs taken in the season, however, were found in the field June 21 st and by July 5 hatching was general and the infestation was showing up very clearly on the unrolling leaves where the newly hatched larvae were feeding at the base. The evidence of attack became clearly marked in the first week in July and by the second week the tassels were falling on the early planted flint and sweet corn. As the plant increased in length and the larvae on the rolled up leaves were exposed to light, they bored into the stalks, which by the end of July in the early planted corn began to break over.

By the third week in July in the very early sweet corn, and to a much less extent in the flint, the majority of the larvae were full grown. At that time a very small second brood developed in the very earliest planted sweet corn, involving but a fraction of one percent of the larvae. In this sweet corn 10 pupae in all were collected between July 21 st and 26th and 4 pupae were secured from larvae collected at the same time. From these pupae, after a periad of 13 days, 2 male moths and 
1 female moth were reared. The female laid fertile eggs, the larvae from which established themselves on a corn plant in an experimental cage. The only other evidences of the second brood were 1 pupa and 2 female pupal cases from the earliest flint corn, an adult male in late July, an egg mass found on August 9th and a few 3d instar larvae taken in August.

The larvae in all varieties of the later corn, matured distinctly later on the average and showed no signs of developing a second brood, but prepared for winter about the middle of August and where not disturbed, would probably not move until spring. At harvest time about the last of August and in early September in a flint corn field showing 70\% total loss, the estimated number of larvae per acre was 191,800. Of these $27 \%$ were within 12 inches of the ground and a four inch stubble carried 28,079 larvae, $6.82 \%$ of the larval population.

There was no movement of any import in the standing field corn in the fall, the distribution in the middle of October being practically the same as at the end of August. However, there is a noticeable movement outward and downward in the stalks in shock, but none of any importance from the shock to the ground and neighbouring stubble.

The date of sowing was closely correlated with the degree of infestation, the larval population and the total loss both in experimental and field conditions. In general, corn sown before May 24th was either practically ruined or suffered severe loss; that sown between May 24th and June 1st was heavily infested but suffered relatively less or but slight actual loss depending of course upon the type of corn; while the corn sown after June 1st, although in some cases showing a fairly high percentage of infestation carried few larvae and practically no loss except in the case of sweet corn. Thus on one farm of the three corn patches within 100 yards of each other, the sweet corn sown April 25 th carried a larval population of 234,200 per acre with a loss of $100 \%$; sweet corn planted June 1st developed an infestation of $75 \%$ and carried a larval population of 80,000 per acre with a loss of $20 \%$ while flint (smut nose yellow) planted May 22d, only carried 54,400 per acre, a stalk infestation of $67 \%$ and a total loss of not more than $10 \%$. The sweet corn here doubtless protecting the flint by attracting a large number of the moths.

In the experimental plots the effect of the date of planting shows up most clearly, as can be seen in the tabulation below, though here the loss was slight and the larval population meagre, the corn all being planted after May 24th. 
Emfect of Date of Pianting on Infestation

\begin{tabular}{|c|c|c|c|c|}
\hline Variety Grown & Date & $\begin{array}{l}\text { Per cent of stocks } \\
\text { infested }\end{array}$ & $\begin{array}{c}\text { Per cent of stocks } \\
\text { broken over }\end{array}$ & $\begin{array}{l}\text { Per cent of cobs } \\
\text { infested }\end{array}$ \\
\hline $\begin{array}{l}\text { Golden Bantam } \\
\text { sweet corn }\end{array}$ & $\begin{array}{l}\text { May 24 } \\
\text { May 31 } \\
\text { June } 3 \\
\text { June } 9\end{array}$ & $\begin{array}{l}30.18 \\
34.4 \\
15.33 \\
7.52\end{array}$ & $\begin{array}{r}16.93 \\
20.00 \\
7.66 \\
4.30\end{array}$ & $\begin{array}{c}16.9 \\
2.14 \\
1.89 \\
1.19\end{array}$ \\
\hline $\begin{array}{l}\text { Dent Corn } \\
\text { Eariy Leaming }\end{array}$ & $\begin{array}{l}\text { May } 31 \\
\text { June } 3 \\
\text { June } 9\end{array}$ & $\begin{array}{r}24.30 \\
13.45 \\
8.11\end{array}$ & $\begin{array}{r}69.44 \\
1.60 \\
1.62\end{array}$ & $\begin{array}{r}.4 \\
.99 \\
1.17\end{array}$ \\
\hline Golden Glow & $\begin{array}{l}\text { May } 28 \\
\text { June } 3 \\
\text { June } 9\end{array}$ & $\begin{array}{r}53.42 \\
21.08 \\
7.44\end{array}$ & $\begin{array}{r}17.81 \\
9.73 \\
4.65\end{array}$ & $\begin{array}{r}2.12 \\
.99 \\
.63\end{array}$ \\
\hline Wisconsin No. 1 & $\begin{array}{l}\text { May } 28 \\
\text { June } 3 \\
\text { June } 9\end{array}$ & $\begin{array}{r}55.44 \\
15.61 \\
3.66\end{array}$ & $\begin{array}{r}16.14 \\
5.35 \\
2.44\end{array}$ & $\begin{array}{l}2.65 \\
1.29 \\
1.16\end{array}$ \\
\hline $\begin{array}{l}\text { Flint Corn } \\
\text { Salzers'North } \\
\text { Dakota }\end{array}$ & $\begin{array}{lr}\text { May } 28 \\
\text { June } & 3 \\
\text { June } & 9\end{array}$ & $\begin{array}{l}70.9 \\
10.62 \\
14.74\end{array}$ & $\begin{array}{r}20.77 \\
10.12 \\
2.17\end{array}$ & $\begin{array}{r}13.31 \\
3.77 \\
4.11 \\
\end{array}$ \\
\hline $\begin{array}{c}\text { Compton's Early } \\
\text {. }\end{array}$ & $\begin{array}{l}\text { May } 28 \\
\text { June } \\
\text { June }\end{array}$ & $\begin{array}{l}82.4 \\
44.14 \\
15.10\end{array}$ & $\begin{array}{r}50.00 \\
17.79 \\
4.17\end{array}$ & $\begin{array}{r}10.47 \\
9.68 \\
3.45\end{array}$ \\
\hline$\overline{\text { Smut Nose Yellow }}$ & $\begin{array}{l}\text { May } 31 \\
\text { June } 3 \\
\text { June } 9\end{array}$ & $\begin{array}{r}30.14 \\
28.57 \\
3.45\end{array}$ & $\begin{array}{l}11.41 \\
14.29 \\
.86\end{array}$ & $\begin{array}{l}6.10 \\
4.11 \\
1.89\end{array}$ \\
\hline
\end{tabular}

The larval population in badly infested fields attained enormous magnitudes; a dent corn field sown May 18th carried an estimated total of 294,152 per acre, a flint field sown on the same day suffered a total loss of at least $65 \%$, supported a total of 258,400 per acre and left when cut, in the stubble (less than 4 inches in height) and the crop refuse, a residue of 43,488 caterpillars going into the winter.

In general, all things considered, there seems to be no marked preference for any particular type or variety of corn. The severe loss associated with sweet corns and the flint varieties being due to the early planting, the ability of the larvae to establish themselves and the small dimension of the stalks. The obvious relatively slight loss in the dent corns being due to the later planting, its vastly greater bulk and its harder and coarser texture preventing a large proportion of the larvae establishing themselves in the first instar.

\section{The Infestation of Plants Other Than Corn}

About the middle of $\mathrm{July}$ in the very severely infested fields of early sweet corn, to a less extent in severely infested flint and to a very slight extent in dent corn except in the one severely injured field, the nearly full grown and full grown larvae become restless. At this time large numbers of them leave the now breaking, shrivelling and drying corn stalks and carry on an apparently haphazard migration throughout a period of about two weeks. In the course of this migration as many as 24,400 larvae per acre found their way into the weeds in one field 
of sweet corn sown April 25th. Others doubtless returned to the corn plants. Considerable feeding was done in the larger weeds, the pigweeds, the lamb's quarters and barnyard grass breaking over in a high percentage of cases. The barnyard grass was as high as $88 \%$ infested and in one instance a plant with 26 stems was found to contain 17 larvae. The weeds infested in this field in the order of frequency were: barnyard grass (Echinochloa crus-galli, Beauv.), redroot pigweed (Amaranthus retroflexus L.), yellow fox-tail (Setaria glauca Beauv.), lamb's quarters (Chenopodium album L.), tumble weed or Russian thistle (Sal-sola var. tenuifolia, G. F. W. Mey), green fox-tail (Setaria viridis Beauv.), lady's thumb (Polygonum persicaria L.), wild buckwheat (Polygonum convolvulus L.), ground cherry (Physalis heterophylla Nees); other weeds present but not infested were : purslane, Canada thistle, bitter sweet, milkweed and crab grass. However, throughout the district of the weeds found to be infested in additon to the above the following can be listed: orchard grass (Dactylis glomerata L.), Canada thistle (Cirsium ariense Scop.), wild sunflower (Helianthus sp.), blue weed or viper's bugloss (Echium vulgare L.), ragweed (Ambrosia artemisiifolia L.); mullein (Verbascum thapsus L.), goldenrod (Solidago sp.), old witchgrass (Panicum capillare L.), yarrow (Achillea millefolium L.), burdock (Arctium minus Bernh.)

In cultivated crops and flowers larvae have been secured in the field feeding in dahlia, geranium, aster, golden glow, beets, mangolds, tomatoes (fruit), beans, oats, squash vines, broom corn, Sudan grass, early amber sugar cane, Hungarian grass and Mann's Wonder sorghum.

No success was achieved in establishing larvae upon a long series of common weeds by attaching eggs laid upon a slip of corn leaf. The eggs hatched but the larvae rarely were able to infest the plant. In a series of experiments with paired adults caged over 35 common cultivated vegetables and flowers, the larvae in very small numbers established themselves upon mangolds, potatoes, celery, cauliflower, peas, beans, peppers, eggplant, radish (gone to seed), salvia and aster. Summing up, however, the entire infestation in the open of plants other than corn, with the exception of the dahlias, possibly barnyard grass and Mann's Wonder sorghum, was due entirely to the migrating larvae. These larvae particularly in the weeds together with those in the corn stalks, stubble and refuse have gone into the winter in very large numbers with every prospect of coming through successfully and giving rise to an increased infestation in 1922.

President Arthur Gibson: The next paper is by L.S. McLaine. 